\title{
Will high-frequency trading practices transform the financial markets in the Asia Pacific Region?
}

\author{
Robert J. Kauffman ${ }^{*}$, Yuzhou Hu and Dan Ma
}

\author{
* Correspondence: \\ rkauffman@smu.ed.sg \\ School of Information Systems, \\ Singapore Management University, \\ 80 Stamford Road, Singapore \\ 198702, Singapore
}

\begin{abstract}
High-frequency trading (HFT) practices in the global financial markets involve the use of information and communication technologies (ICT), especially the capabilities of high-speed networks, rapid computation, and algorithmic detection of changing information and prices that create opportunities for computers to effect low-latency trades that can be accomplished in milliseconds. HFT practices exist because a variety of new technologies have made them possible, and because financial market infrastructure capabilities have also been changing so rapidly. The U.S. markets, such as the National Association for Securities Dealers Automated Quote (NASDAQ) market and the New York Stock Exchange (NYSE), have maintained relevance and centrality in financial intermediation in financial markets settings that have changed so much in the past 20 years that they are hardly recognizable. In this article, we explore the technological, institutional and market developments in leading financial markets around the world that have embraced HFT trading. From these examples, we will distill a number of common characteristics that seem to be in operation, and then assess the extent to which HFT practices have begun to be observed in Asian regional financial markets, and what will be their likely impacts. We also discuss a number of theoretical and empirical research directions of interest.
\end{abstract}

Keywords: Asian region; Equity markets; Financial innovation; Financial IS and technology; Financial markets; High-frequency trading (HFT); Market transformation; Technological innovation

Since the mid-2000s, the average trade size in the U.S. stock market had plummeted, the markets had fragmented, and the gap in time between the public view of the markets and the view of high-frequency traders had widened. The rise of high-frequency trading had been accompanied also by a rise in stock market volatility-over and above the turmoil caused by the 2008 financial crisis. The price volatility within each trading day in the U.S. stock market between 2010 and 2013 was nearly $40 \%$ higher than the volatility between 2004 and 2006, for instance. There were days in 2011 in which volatility was higher than in the most volatile days of the dot-com bubble.

Author Michael Lewis ((2014), p. 59) in The Flash Boys: A Wall Street Revolt

\section{Springer}

(c) 2015 Kauffman et al. This is an Open Access article distributed under the terms of the Creative Commons Attribution License (http://creativecommons.org/licenses/by/4.0), which permits unrestricted use, distribution, and reproduction in any medium, provided the original work is properly credited. 
The SEC should not roll back the technology clock or prohibit algorithmic trading, but we are assessing the extent to which specific elements of the computer-driven trading environment may be working against investors rather than for them. An area of particular focus is the use of aggressive, destabilizing trading strategies in vulnerable market conditions, when they could most seriously exacerbate price volatility.

U.S. Securities and Exchange Commission Chair Mary Jo White, June 2014, quoted by Shorter and Miller (2014)

\section{Introduction}

Over hundreds of years around the world, securities were traded through physical venues where buyers and sellers met and negotiated the exchange of ownership of securities and assets. An example in the history of American financial markets is the "Buttonwood Agreement" of May 1792, involving 24 stockbrokers in New York (Terrell 2012). The group established an early basis for the New York Stock Exchange by agreeing to trade with one another and no others, and to set a minimum commission for share trading. They initially met under an American sycamore tree - the so-called "buttonwood tree," at 68 Wall Street in lower Manhattan. This approach to making trades later moved to purpose-build financial exchange facilities and trading floors, where traders wore brightly-colored jackets, shouted out their bid and ask prices to buy and sell shares, and made themselves stand out from the crowd in the open outcry marketplace.

\section{Transformation in the Financial Services Industry via Information Technology}

With the recent developments and innovations in information technology (IT), the financial services sector has been transformed over several decades (Steiner \& Teixeira 1989; Wriston 1988, 2007). In the 1800s, the use of the telegraph to connect American cities and the Atlantic Cable to connect New York and London created the first instances when it was possible to exploit financial market-related informational advantage for trading in the U.S. regional and U.K. national markets (Kavesh et al. 1978). Starting in the 1970s, the trading process became computerized, and manual trading processes were targeted for elimination. Then, in the 1980s, program trading emerged and trades were sent to market based on computer software and algorithms (Hasbrouck et al. 1993). By the end of 1990s, the emergence of electronic communication networks (ECNs) further changed trading on the National Association of Securities Dealers Automated Quote (NASDAQ) and New York Stock Exchange (NYSE) (Stoll 2006). This made it possible to extend daytime trading into overnight crossing market operations. In 1998, with the passage of the Regulation on Alternative Trading Systems (Regulation ATS) (Securities and Exchange Commission 1998), ECNs became more popular. Some brokerages set up new ECNs, which in turn led to more use of algorithmic trading (Aldridge 2013).

High-frequency trading (HFT), also called algorithmic trading, is an imprecise term that currently has no legal or regulatory definition. (See Appendix: Table 3 for a listing of all of the technical terms in this article, along with their definitions.) It is used to describe a subset of algorithmic trading activities largely associated with the sell side of the financial industry. Algorithmic trading is the use of computer algorithms to automatically make trading decisions, submit securities trades, and manage securities orders after their submission (Investopedia 2015). A 2010 (Securities and Exchange Commission 2010, p. 45) 
report on market structure offers a detailed description of HFT practices, which involve: "(1) the use of extraordinarily high-speed and sophisticated computer programs for generating, routing, and executing orders; (2) use of co-location services and individual data feeds offered by exchanges and others to minimize network and other types of latencies; (3) very short timeframes for establishing and liquidating positions; (4) the submission of numerous orders that are canceled shortly after their submission; and (5) ending the trading day in as close to a flat position as possible (... not carrying significant, unhedged positions overnight)." It is typical that high-frequency traders end their trading day by squaring up their positions, so they are neither long nor short. They do this to reflect the fact that they trade on information moment to moment, rather than with longer-term strategies from day to day. Numerous authors have recognized the potential for controversy, problems, and legal issues (McGowan 2010).

The securities trading landscape in the presence of HFT practices is characterized by more intense competition for order flows, faster connections between buy and sell-side firms and the exchanges, cooperation between high-frequency traders and exchanges, the emergence of a rich ecosystem of technology providers, and the promulgation of regulations that ensure HFT does not damage market quality. Like other settings where new and advanced technologies are used, HFT technologies enable their adopters to gain legitimate returns on investment (ROI) from their investments, as well as compensation for their market, counterparty and operational risk exposures. The adopters of HFT practices compete to connect their trading capabilities for the financial markets as fast as possible, so they can be faster than the competition. For the market venues, they compete to attract orders and liquidity providers. Many exchanges now provide beneficial services to highfrequency traders, such as direct connections to exchange data and co-location services.

Typical HFT traders include mutual and pension funds, and other sophisticated investors. Innovative HFT practices first appeared in U.S. financial markets, and then expanded to Europe and Asia. The Tabb Forum (2014) reported that HFT activities accounted for $49 \%$ of the trading volume in the American equity markets in 2013. HFT accounted for about $40 \%$ of all equity trades in the European market in 2009, according to a European Parliament report (Swinburne 2010). More recently, HFT practices have been diffusing into the markets in other countries, as the technology capabilities of western countries have extended their influence worldwide. For example, HFT practices have now penetrated all of the major financial markets in the Asia Pacific region although HFT accounted for only about $12 \%$ of total trading by value on the regional stock exchanges in 2011, excluding Japan and Australia, according to research by Schroders reported in Price $(2013)^{2}$.

\section{Toward Understanding Issues with HFT Practices in Global Markets}

With this background in mind, we ask a number of questions. How have HFT practices been transforming the financial markets in the Asia Pacific region? To what extent have these practices penetrated market exchange of equities, and what issues have arisen around these changes? Have the changes been different for different countries and national markets? What research questions are worthwhile exploring in this context, and what policy issues will need to be addressed? This article offers an overview of HFT practices in different markets around the world, with specific interest in the financial markets in the Asia Pacific region. 
Though HFT has been gaining global popularity, it still faces a unique set of challenges that raise questions about regulations. The Flash Crash of May 6, 2010 sent a wake-up call to investors and regulators. HFT practices have been criticized for skimming profits at the expense of ordinary investors, and manipulating the market (Biais \& Woolley 2011). In contrast, some experts have argued that these trades play an important role in the market by providing both liquidity and price discovery while lowering transaction costs. As a result, there has been debate around the issue that regulations on high-frequency traders should be cautiously evaluated, so that the market is not frozen and trading is not driven away. Nevertheless, numerous investigations have been initiated to assess the impact of HFT practices on market quality (Brogaard et al. 2014, Hendershott et al. 2011, Jarrow \& Protter 2012), and all of the major financial markets have established their own regulations related to HFT. As the debate over HFT has grown, observers have wondered how trading technology will evolve in next decade, whether high-frequency trading will become even more widely dominant, and how it will be regulated.

This article is laid out in the following way. Section 2 provides an overview of HFT activities in the American and European financial markets, while Section 3 examines them in the regional financial markets of the Asia Pacific area. Section 4 considers competition, cooperation, and regulation in these markets. Section 5 proposes new research directions, and Section 6 concludes.

\section{The rise of high-frequency trading}

We next will discuss securities-related technology evolution, and the rise of HFT in the American and European markets, where technological innovation resulted in new practices, issues, and regulatory solutions.

\section{Background: Technology Evolution for HFT Practices}

Ever since its debut in the financial markets in the early 2000s, HFT has gained popularity and usage at an astonishing speed, transforming the securities trading mechanisms of all the financial markets around the world. Traditional floor-based trading is being gradually phased-out, as more and more investors have chosen to work with firms that employ algorithmic trading approaches.

In fact, securities trading mechanisms have been in a continuous state of evolution since 1602, when the Amsterdam Stock Exchange was launched as the world's first stock exchange (Petram 2011). In the beginning, the volume of securities traded and the number of traders involved in various marketplaces was always very small, but they grew in Amsterdam and elsewhere over time. In the 1960s, financial information still spread rather slowly, typically through ticker tapes, and phone-based communication was expensive (Brummer 2008). Trading was almost always a manual process.

Once the exchanges started to implement computerized communications, securities trading could be conducted much faster. This permitted traders to be connected to a trading platform rather than to be physically present on trading floors. In 1971, NASDAQ (2015) became the world's first electronic stock market, by introducing an electronic price and quantity quotation system for competing market-makers to trade securities. A few years later in 1976, the NYSE introduced the "designated order turnaround" (DOT) system, which supported electronic transmission of orders to buy and 
sell securities (Keith \& Grody 1988). Floor-based trading mostly ended in the 1980s, and program and electronic trading became more popular since then (Hasbrouck et al. 1993). Program trading is defined as buying or selling fifteen or more stocks with total value over USD 1 million dollars, and was mostly used for trading in the S\&P 500 equities and futures markets (Tagliani 2009).

With the emergence of ECNs in the 1990s, investors began to be able to trade outside traditional exchanges and beyond the normal exchange trading-hours. ECNs match buy and sell orders automatically and connect individual investors with large brokerages directly, so they can trade with each other without going through a middleman (Weston 2002). Compared with other trading channels, ECNs have been able to reduce costs and trading errors, enhance operational efficiency, and provide benefits for overnight risk management.

Just a few years later, algorithmic trading and HFT became prevalent in securities trading. And today, HFT practices dominate the majority of trading activities in U.S. securities. The markets in the U.S. employ extremely fast trading facilities and sophisticated computer programs. Orders are generated, routed and executed automatically and quickly, with hundreds of trades being completed within milliseconds (United States Commodity and Futures Trading Commission 2012). There are several reasons that account for the rise of HFT practices. One is the development of new technologies that have made high-speed program trading possible, with lower and lower costs for the implementation of such trading systems over time (Mehta 2009). The other reason is that the major exchanges, including NASDAQ, the Better Alternative Trading System (BATS) market, and the NYSE, have responded to the demand from traders by offering faster access to their trading infrastructures and direct connections to their trade data transmissions (Sorkin 2014).

There are other reasons as well. The SEC adopted decimalized prices in 2000. This decision directed stock exchanges to quote share prices in decimal form instead of using the traditional fractions, which supported wider spreads (Securities and Exchange Commission 2012). This made traditional market-making less profitable, reduced the size of securities trades, and enhanced the demand for more sophisticated computerized trading. After 1998, when more ECNs were registered and set up by brokerage firms, the number of trading venues that supported algorithmic trading further increased. Then, during the years leading up to the mid-2000s, the SEC sought to ensure that all of the existing domestic exchanges were linked together, so their prices would be more easily accessed to support more efficient market trading. This resulted in the SEC's 2005 promulgation of the Regulation National Market System (NMS) (Bunge 2014, Securities and Exchange Commission 2005), which enabled the current trading mechanisms.

HFT practices have spread around the world in a short time. The U.S. and European financial markets have experienced many changes as a result of this, including the implementation of sophisticated trading technologies all the way to changes in their regulatory frameworks for securities trading. Figure 1 presents data on HFT growth from 2005 to 2014 for the U.S. and European Union as a percentage of the total turnover for equity trading.

In 2005 in the U.S., HFT was estimated to be about $21 \%$ of all trades by volume, while in Europe it had hardly begun, and so was close to $1 \%$ by value (Credit Suisse 2014). From 2006 to 2009, the growth of HFT was rapid. It accounted for $61 \%$ by volume of the entire equity turnover in the U.S. in 2009, up from $52 \%$ in 2008. Similarly, in Europe, HFT as a percentage of total equity turnover by value also grew rapidly to around $29 \%$ in 2009, up from $21 \%$ just a year earlier in 2008 . 


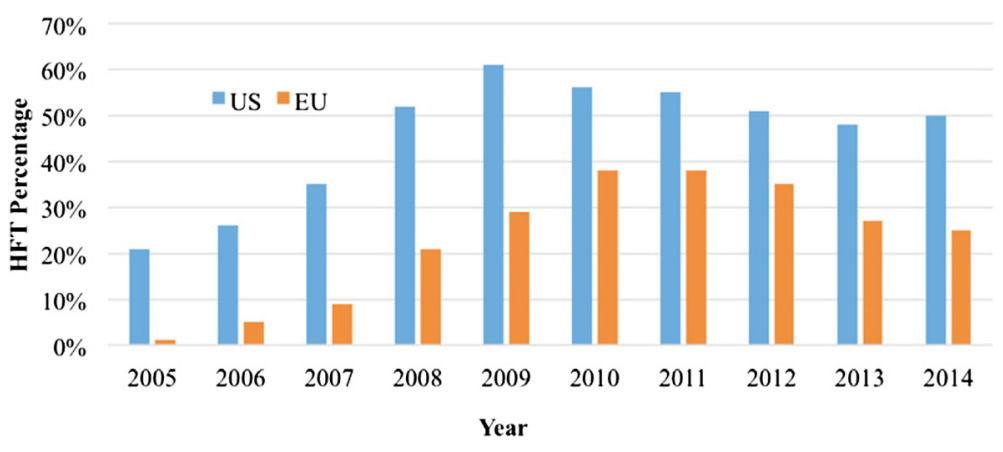

Fig. 1 Percentage of HFT Equity Turnover, 2005-2014, Relative to All Market Activity

The rate of growth of HFT continued in the European Union for another year, reaching $38 \%$ of equity turnover value in 2010 and 2011. But HFT began to decline in the U.S. in the same period. In 2010 and 2011, it fell to $54 \%$ to $56 \%$, respectively, of the total volume, and then stabilized at close to 50 \% in 2012, 2013 and 2014. European HFT also fell back to about $35 \%$ in 2012, and then went below $30 \%$ in 2013 and 2014. So there does not appear to be upward movement in HFT growth going forward (Phillips 2013, Popper 2012b).

\section{The spread of HFT practices in the Asia-Pacific region}

In contrast to the U.S. and the European Community, HFT activities in the Asia Pacific region account for only $12 \%$ of total trading by value in stocks on exchanges, excluding Japan and Australia, as we noted earlier. The financial markets in the Asia Pacific region are more diversified than those in Europe and America, and have had more mixed responses to HFT. See Table 1 for an overview of HFT activities in this region. Only Japan and Australia have embraced the new algorithmic trading approaches, with HFT penetration rates of $45 \%$ (Grant 2011) and $27 \%$ (Australian Securities and Investments Commission 2013, Kingsley et al. 2013), respectively.

Most of the major Asia Pacific financial markets are going through fundamental changes too. For example, Jaswal (2010) has reported that the financial markets in this region have been moving towards greater efficiency through employing more HFT methods in the markets they serve. And CapGemini has suggested that proprietary firms will play a large role in developing HFT in the region (Agarwal 2012). We next will discuss the major Asia Pacific markets in greater detail. See Appendix: Table 4 for an overview of the related HFT adoption accelerators and decelerators.

Table 1 Proportion of HFT Activities in the Asia Pacific Region

\begin{tabular}{lll}
\hline Country & Estimate & Information Source \\
\hline Japan & $45 \%$ of equity trading & Bank of Japan \\
Australia & $27 \%$ of equity trading & Australian Securities and Investments Commission \\
Hong Kong & $20 \%$ of equity trading & Hong Kong Securities and Futures Commission \\
Singapore & $\sim 30 \%$ in derivatives, $\sim 0$ in equities & Singapore Stock Exchange \\
\hline
\end{tabular}


Japan

Tokyo has been the leading venue for HFT in the Asia Pacific region, and it is estimated that HFT accounts for $45 \%$ of the equities trading volume there (Grant 2011). The Tokyo Stock Exchange (TSE) has made upgrades to its trading systems in an attempt to encourage an increase in HFT, and the regulations and financial market structure are also favorable for HFT growth (Fujitsu 2010, Wang 2010, World Federation of Exchanges 2013). For example, in January 2010, to enhance its competitiveness in HFT, the TSE launched the Arrowhead trading platform to improve its trading speed and security (Bershova \& Rakhlin 2013). After its introduction, order response time decreased to ten milliseconds, although TSE officials claimed that they favored stability over speed in the Arrowhead's platform's design (Yoon 2010). In addition, the level of HFT activities is sensitive to trading fees in the markets, and the TSE in Japan is fortunate to have relatively low transaction costs. In fact, in 2010, Japan and Sweden shared the world's lowest-cost trading value crown, with an average cost of only 18.34 basis points (Byrne 2010).

The broader Japanese market is fragmented enough so that HFT participants are able to explore price inefficiencies for stocks across the different domestic exchanges. Among the various exchanges in Japan, the TSE ranks first in trading volume and trading value, with $90 \%$ of the common stock (or cash equities) volume in Japan occurring there. The other $10 \%$ of trades are made via private trading systems, such as Chi-X Japan and SBI JapanNext. In 2013, the TSE merged with the Osaka Security Exchange (OSE) to form the Japan Exchange Group (JPX), indicating the willingness of domestic exchanges there to work together to combat competition from abroad (Ito 2013).

In financial markets, a lower tick size, which is the minimum unit for the movement of the price of a financial instrument, creates opportunities for identifying arbitrage opportunities (Chordia et al. 2013, Menkveld 2013). This is an essential factor for implementing HFT trading strategies that will create business value (Chlistalla 2011, Comerton-Forde 2012). JPX has embarked on a three-phase move to reduce its tick size, bringing it into line with the tighter increments that exist on Japanese proprietary trading systems, Chi-X Japan and SBI JapanNext (Umeno and Matsubara 2014). In the first phase, JPX initially implemented one-half Japanese yen (JPY) price ticks for TOPIX 100 companies with JPY 3,000 to JPY 5,000 share prices. The tick size was moved up to one yen in the second phase, which began in July 2014 (Takeo \& Hasegawa 2014). In the third phase, which is scheduled to begin in mid-2015, JPX will re-examine the appropriateness of the present tick size based on its impact on trading conditions and execution costs.

\section{Australia}

Australia's HFT activities in its financial market have been limited to date. There are globally-recognized HFT traders that are participating in the Australia markets, including Getco and Virtu Financial (Comerton-Forde 2012). These traders execute their deals in the two largest exchanges, Chi-X Australia and the Australia Securities Exchange (ASX). There are also other HFT traders that conduct their trading activities outside these two exchanges. These firms route their orders to alternative trading venues, such as dark pools, where it is not possible to acquire public information to directly gauge the extent of their trading activities. As a result, even the regulators in Australia have difficulty to obtain a full understanding of the overall extent of HFT activities in the nation's financial market. 
We noted earlier that HFT trades represented $27 \%$ of Australian trading volume in 2012. The Australian financial markets exhibit a number of favorable characteristics for HFT growth, such as the low latency in network communications and low transaction costs. There are only three trading venues in Australia: ASX TradeMatch, ASX PureMatch and Chi-X. In comparison, the U.S. has thirteen exchanges and over fifty alternative trading systems. Thus, the Australian markets are less fragmented, so there may not be the same potential for growth in HFT activity in Australia that the U.S. offered.

Competition between trading venues also pressures the exchanges to upgrade their trading facilities, as well as to provide services and cut stamp duties for changing securities ownership. For example, ASX recently upgraded its trading technology and launched its own low latency platform, PureMatch, to compete directly with Chi-X (Comerton-Forde 2012). In addition, ASX enhanced its co-location facilities, but it no longer offers transaction rebates for large participants or large volumes (Australian Securities Exchange 2010). Competition among exchanges has also brought with it lower trading fees. This is demonstrated by ASX's reduction of its trading fees from 0.28 basis points (bps) down to 0.15 bps. Meanwhile, Chi-X also launched a makertaker pricing model (Mishkin 2011). This has resulted in differential fees being charged to trading firms depending on whether they provide or demand liquidity. These changes make Australia a more attractive place for HFT traders to operate.

\section{Singapore}

The Singapore Exchange (SGX) is the largest financial market in Southeast Asia. It has suffered from decreasing securities trading activities in the past few years though. According to data from SGX, in 2013 there was a $36 \%$ plunge in the daily average value of equity trades compared to the level of trading that occurred in 2007 (Burgos 2013). SGX's net income was SGD 336 million in the fiscal year ending in June 2013, 20 \% lower than in 2007. To boost trading volume in the equities and derivatives market, the exchange wanted to lure more HFT traders to SGX. To achieve this goal, SGX initiated a series of technology improvements. For example, in 2013, it launched a new and ultra-fast trading engine called "SGX Reach," in a bid to attract HFT traders. This represented part of a SGD 250 million investment for technology improvements, aimed to boost trading speed and international connectivity (Malakian 2011).

The Singapore Exchange also has started to offer co-location services to its clients. As of 2011, it had about 100 clients that house their computers for trading nearby the SGX's servers. Co-location supports faster trading by cutting the latency of reaction times. The Malaysian bank, Commerce International Merchant Bankers Berhad (CIMB), was the first broker-dealer to place its online trading platform at SGX's co-location center, allowing retail investors to achieve trades in 100 microseconds (The Trading Mesh 2011a).

Even with all of the above-mentioned initiatives, the SGX has not been successful in attracting orders from HFT traders yet though. Two factors seem to explain this outcome. First, high trading costs keep HFT firms away from SGX. Fees for trading on the Singapore Exchange amount to about 20 bps of the value of shares traded, compared with Sydney-based ASX's 15 bps (Burgos 2013). Also, Singapore does not have a fragmented financial market like the U.S. does: Singapore is too small a country, and has just one stock exchange. Thus, there is no arbitrage opportunity existing among different trading venues for equities. The only arbitrage opportunities that exist are mainly 
in the derivatives market, where about $30 \%$ of the total volume of trades is attributable to high-frequency traders. With derivatives contracts, traders can exploit inefficiencies involving parallel products that trade elsewhere in the world.

Along with these changes, Burgos (2013) also reported that the Monetary Authority of Singapore (MAS), in its role as the regulator of securities trading under the nation's Securities and Futures Act (SFA), has encouraged the SGX to create new market safeguards for problems that may arise related to HFT trading in advance of seeking to expand such trading. The changes to be implemented include circuit breakers to stop trading when a given equity experiences high intraday price volatility, as well as risk controls that are put into play during the pre-trade phase. An innovative approach that SGX has undertaken involves the application of the algorithm that establishes the single prices at which buy and sell market orders are matched in the opening and closing routines for trading in the beginning and end of the day with the randomization of application time (Singapore Exchange 2012). This is to avoid the rigging of order submissions in anticipation of the end of the time period when price matches are made final.

\section{Hong Kong}

Over the years, Hong Kong has been recognized as one of the pre-eminent Asian financial centers. In comparison to the Japanese financial markets, where HFT traders have been engaged in an arms race for high-technology trading, Hong Kong's regulators have been hesitant to permit the adoption of the same type of competition that drives trading by the millisecond.

According to a 2013 report of the regulatory organization, the Hong Kong Securities and Futures Commission (SFC), approximately $20 \%$ of trading volume was represented by HFT activities in 2012 (Kingsley et al. 2013). The financial market environment in Hong Kong is not that favorable for the growth of HFT practices. Similar to some other countries, the high stamp duty for ownership transfer of securities creates the greatest push-back against HFT in Hong Kong's equity market. The SFC levies taxes of $0.1 \%$ on the purchase and sale of shares, which makes HFT strategies unprofitable (Gov.HK 2013). Many HFT firms that came to Hong Kong in hopes of making money actually failed and were forced to leave. An example is the U.S.-based HFT trader, Getco, which closed its Hong Kong office in March 2013 (Bunge 2013).

By the same token, the Hong Kong financial market does not suffer from fragmentation. The Hong Kong Exchanges and Clearing (HKEx) organization enjoys a nearmonopoly in share trading, due to local rules stipulating that all trades must be reported to the exchange. Similar to Singapore and other markets in different parts of the world, Hong Kong can grow the extent to which derivatives are traded using HFT approaches, but significant investments in technology will need to be made in order to improve the country's competitive ability to serve traders in the global markets.

\section{China}

China is another country that has not been attractive for HFT practices to diffuse its internal markets. There are barriers to the wide application of HFT in the country's financial markets. First, the regulatory environment for HFT practices in China are not favorable, and the network communication latency levels in Chinese exchanges are not conducive to fast trading (Grant 2012). Second, equity trading is subject to the $T+1$ 
regulation, which forbids the selling of stocks in the same day when it was bought. Futures traders, in contrast, can deal in the same instrument up to 500 times each day, but even this limit is still too small in comparison to what HFT traders typically do. So this $\mathrm{T}+1$ regulation puts a major constraint on HFT execution. Third, the technologies that are in use in China's futures markets are still below the technology required by most HFT traders, who usually have high requirements for streaming data on equities and derivatives prices, and demand millisecond updates.

Fourth, the cost of trading in China is relatively high, with stamp duties fluctuating between $0.1 \%$ and $0.3 \%$ for the sellers of securities. And finally, China's regulations with respect to high-frequency trading have not yet been liberalized to promote the growth of these practices. The case of trading errors and losses at state-owned Everbright Securities in 2013 demonstrated the vulnerabilities that may arise when HFT practices are used (Miller \& Wildau 2013, Sun 2013). This effectively prohibits any significant development of HFT activities in this market.

In the future, HFT will gain the opportunity to develop further in China only as more assets come to market, and as trading restrictions and costs diminish. The introduction of low-latency technologies for traders and exchanges may support the growth in the proportion of HFT for equities relative to the country's total trading volume.

To sum up, we note that changes are gradually occurring at the market structure-level throughout the major Asia Pacific financial markets. As firms have sought new opportunities with HFT practices across the globe, a few obstacles have become apparent though, according to industry advisor, the Aite Group (2011). The firm suggests that these obstacles include: the potential for political and regulatory instability; the lack of capability and consistency in the IT infrastructures of emerging markets; and the existence of protectionist policies to insulate domestic exchanges and financial services firms from external competition. The Aite Group also notes the importance of: the exorbitant costs of developing a local presence in an Asia Pacific financial market, and the lack of a viable third-party vendor community to provide support for the development of high-capability HFT operations.

The Aite Group ((2011), p. 10) has further written that, "[d]espite these hurdles, the globalization of financial markets will continue, as firms look to diversify their risk and optimize their existing organizational and IT infrastructures." So, although the penetration of HFT in the Asian financial markets has not been rapid or widespread, we nevertheless have offered an assessment of the drivers and barriers to the wider adoption and diffusion of HFT in the region.

\section{The roles of competition, cooperation, and regulation}

We next will discuss competition and cooperation among different stakeholders in HFT trading activities, as well as regulation at the country level.

\section{Competition and Cooperation}

The emergence of HFT has led to an arms race for speed among traders. In order to outperform their competition, HFT firms must keep improving their capabilities in different ways. They have all invested significantly in low-latency technologies so that they can trade faster than their competitors. Being faster by just several microseconds supports the identification of arbitrage opportunities, which will permit greater profitability. In addition, they demand smarter trading algorithms that are updated and 
upgraded constantly in order to stay ahead of competition, since trading algorithms are vulnerable to reverse engineering by rival firms. High-frequency traders, thus, are looking to recruit the best and brightest programmers from the world's top universities, to ensure that they can remain competitive in the market. In general, such competition among high-frequency traders has a positive impact on the market. It serves to reduce bid-offer spreads and transaction costs for all participants in the financial markets, including institutional and individual clients. The competition among HFT firms with respect to low-latency communications capabilities is related to their desire to become involved in front-running, the practice of equity trading on behalf of the firm itself, and not giving first priority to supporting trades by clients, who do not yet have access to the same information.

Many researchers have studied the market transformation impacts of HFT competition. Most of them found positive effects. For example, Hendershott et al. (2011) utilized a dataset of NYSE electronic message traffic to test the impact of algorithmic trading on liquidity. They showed that algorithmic trading led to the narrowing of bidask spreads, reduced adverse selection, accelerated trade-related price discovery, and increased market liquidity. Hendershott \& Riordan (2013) used data from the firms listed on the Deutsche Boerse DAX, where algorithm trading supplied $50 \%$ of the liquidity. They found the similar: algorithm trading increased the efficiency of the price discovery process. More recently, Chaboud et al. (2014) studied the impact of algorithmic trading in the foreign exchange market using a long time series of high-frequency data, and also found an improvement in the price efficiency after using algorithm trading, and fewer arbitrage opportunities for slower traders.

To support HFT practices, trading venues such as the stock exchanges have to overhaul their existing infrastructures, set up new trading and pricing rules, and adapt to changing market microstructures, which will enable them to compete for market share more aggressively. In the U.S. over the last two decades, massive changes have been seen in the IT infrastructure of financial markets. All the trading venues in U.S. have upgraded their IT infrastructures to support microsecond-level activities in trading. They also are providing co-location and proximity access solutions to meet HFT participants' demand for lowlatency telecommunication services, in the fight fir pricing and information distribution to support more investor participation (Aite Group 2011, Gomber et al. 2011).

Chlistalla (2011) has reported on an interesting new development involving the asymmetric pricing of trades. Exchanges are able to price-discriminate among traders and their orders, and in this way, discourage too much trading that reduces liquidity as investors sell their shares, by charging them a higher fee. The distinction, according to the author, is between liquidity-takers and liquidity- makers. The latter bring new demand to the market to purchase shares, so that the heavy sales by the former do not dominate.

The enhancement of data availability and the modification of fees for trading have also been occurring in Europe. The primary foundation for securities market regulation is embodied in the European Union's November 2007 Markets in Financial Instruments Directive (MiFID), which changed the regulatory regime involving securities transaction reporting and data sharing (SWIFTRef 2015). Chlistalla (2011) have suggested that the European exchanges changed their fee structures, making them more advantageous for HFT participants. The obvious conclusion is that this will be beneficial for the markets, so long as HFT practices are viewed liquidity-making rather than liquidity-taking. 
The financial markets in the Asia Pacific region are making gradual changes in their trading infrastructures and operating rules to become more HFT-friendly too. In January 2010, to enhance its competitiveness, the Tokyo Stock Exchange (TSE) launched the Arrowhead trading platform to improve its trading speed and security, as we noted elsewhere (Bershova \& Rakhlin 2013). Table 2 presents a brief description of some of the other new IT initiatives within the major Asia Pacific financial markets (Gomber et al. 2011).

Cooperation and competition in HFT go together. To upgrade or rebuild an exchange trading platform for fast order processing capability, cooperation among a group of stakeholders, including the trading exchange, technology and infrastructure providers, and third-party software providers, is required. The development of effective risk management practices are also needed to satisfy the safety and security needs HFT traders. In many cases, high-frequency traders must actively collaborate with exchanges to reach win-win cooperative outcomes. For example, in the race to zero latency, highfrequency traders typically will make payments to the exchanges or the ECNs for the access to two types of services: direct connections to trading data; and co-location services that enable traders to place their servers in the same data center that hosts an exchange's or an ECN's market data system (Rogow 2012). Direct connection services give HFT participants earlier access to trading data than conventional investors, who can only get their data through value-added services providers, such as the Consolidated Tape Association (CTA) which is related to the NYSE. Co-location services permit HFT traders to minimize the transmission time between their own trading servers and the systems operated by exchanges, which exacerbates the speed advantage of high-frequency traders. Such practices also have led to the accusation that HFT traders have unfair advantage. Many observers believe that it should be left to regulators to decide what is right to do (Shorter \& Miller 2014).

The SEC should not roll back the technology clock or prohibit algorithmic trading, but we are assessing the extent to which specific elements of the computer-driven trading environment may be working against investors rather than for them. An area of

Table 2 New Technology Initiatives at Four Stock Exchanges

\begin{tabular}{|c|c|c|c|c|}
\hline Exchange & Initiative & Launch & Details & Latency and Capacity \\
\hline $\begin{array}{l}\text { Toronto } \\
\text { Stock } \\
\text { Exchange } \\
\text { (TSE) }\end{array}$ & Arrowhead & January 2011 & $\begin{array}{l}\text { Next-gen low-latency trading } \\
\text { platform, co-location service }\end{array}$ & $\begin{array}{l}\text { Matching engine processing } \\
\text { speed of } 5 \text { milliseconds, } 4.68 \\
\text { million orders/day }\end{array}$ \\
\hline $\begin{array}{l}\text { Australia } \\
\text { Stock } \\
\text { Exchange } \\
(\text { ASX) }\end{array}$ & ASX Trade & December2010 & $\begin{array}{l}\text { Next-gen low-latency trading plat- } \\
\text { form; derivatives, cash mkts; NAS- } \\
\text { DAQ OMX Genium INET platform }\end{array}$ & $\begin{array}{l}\text { Matching engine processing } \\
\text { speed of } 300 \text { microseconds, } \\
100,000 \text { orders/second }\end{array}$ \\
\hline $\begin{array}{l}\text { Hong Kong } \\
\text { Stock } \\
\text { Exchange } \\
\text { (HKEx) }\end{array}$ & $\begin{array}{l}\text { Upgrade } \\
\text { AMS }\end{array}$ & $\begin{array}{l}\text { December } \\
2011\end{array}$ & $\begin{array}{l}\text { Plans to improve latency, capacity of } \\
\text { existing platform }\end{array}$ & $\begin{array}{l}\text { Matching engine processing } \\
\text { speed of } 9 \text { milliseconds, } \\
30,000 \text { orders/second }\end{array}$ \\
\hline $\begin{array}{l}\text { Singapore } \\
\text { Stock } \\
\text { Exchange } \\
(\text { SGX) }\end{array}$ & Reach & August 2011 & $\begin{array}{l}\text { Next-gen low-latency trading plat- } \\
\text { form; cash markets; NASDAQ OMX } \\
\text { Genium INET platform }\end{array}$ & $\begin{array}{l}\text { Matching engine processing } \\
\text { speed of } 90 \text { microseconds, } 1 \\
\text { million orders/second }\end{array}$ \\
\hline
\end{tabular}

Source. Aite Group (2011) 
particular focus is the use of aggressive, destabilizing trading strategies in vulnerable market conditions, when they could most seriously exacerbate price volatility.

U.S. Securities and Exchange Commission Chair Mary Jo White, June 2014, quoted by Shorter \& Miller (2014)

Meanwhile, some exchanges are seeking a way to get ahead of the competition through cooperation. They express an interest to combine their resources and capabilities to increase their global competitiveness. For years, NYSE Euronext and Deutsche Boerse have been trying to merge, signaling that the financial markets are becoming more consolidated than before. It is no longer enough for an exchange to focus only on its domestic market. Instead, it should be open to possible opportunities outside the country or region, and to expand its global influence. Many major financial markets in the Asia Pacific region have already started the consolidation process. In 2013, the Tokyo Stock Exchange (TSE) merged with Osaka Securities Exchange (OSE), making it the world's third-largest exchange based on the number of listed companies, for example. This demonstrates a willingness on the part of the exchange to cooperate to perfect their market mechanisms and coverage.

\section{Regulation}

Regardless of the positive effects of HFT that offers, such as reduced spreads, higher liquidity, and faster price discovery, its negative side is mostly what has caught people's attention. Several notorious market failures and accidents in recent years all seem to be related to HFT practices. They showed how much risk HFT can involve and how huge the damage can be.

HFT heavily depends on the reliability of the trading algorithms that generate, route, and execute orders. High-frequency traders thus must ensure that these algorithms have been tested completely and thoroughly before they are deployed into the live systems of the financial markets. Any improperly-tested, or prematurely-released algorithms may cause losses to both investors and the exchanges. Several examples demonstrate the extent of the ever-present vulnerabilities.

In August 2012, the Knight Capital Group implemented a new liquidity testing software routine into its trading system, which was running live on the NYSE. The system started making bizarre trading decisions, quadrupling the price of one company, Wizzard Software, as well as bidding-up the price of much larger entities, such as General Electric. Within 45 minutes, the company lost USD 440 million (Perez 2013). After this event and the weakening of Knight Capital's capital base, it agreed to merge with another algorithmic trading firm, Getco, which is the biggest HFT firm in the U.S. today (Popper 2012a). This example emphasizes the importance of implementing precautions to ensure their algorithms are not mistakenly used.

Another example is Everbright Securities in China. In 2013, state-owned brokerage firm, Everbright Securities Co., sent more than 26,000 mistaken buy orders to the Shanghai Stock Exchange (SSE of RMB 23.4 billion (USD 3.82 billion), pushing its benchmark index up $6 \%$ in two minutes (Miller \& Wildau 2013). This resulted in a trading loss of approximately RMB 194 million (USD 31.7 million) (Sun 2013). In a follow-up evaluative study, the China Securities Regulatory Commission (CSRC) found that there were significant flaws in Everbright's information and risk management systems (China Daily 2013). 
The damage caused by HFT errors is not limited to specific trading firms themselves, but also may involve stock exchanges and the stability of the related financial market. On Friday, May 18, 2012, the social network giant, Facebook's stock was issued on the NASDAQ exchange. This was the most anticipated initial public offering (IPO) in its history. However, technology problems with the opening made a mess of the IPO. It attracted HFT traders, and very large order flows were expected, and before the IPO, NASDAQ was confident in its ability to deal with the high volume of orders.

But when the deluge of orders to buy, sell and cancel trades came, NASDAQ's trading software began to fail under the strain. This resulted in a 30-minute delay on NASDAQ's side, and a 17-second blackout for all stock trading at the exchange, causing further panic. Scrutiny of the problems immediately led to fines for the exchange (Popper 2013) and accusations that HFT traders bore some responsibility too (Levine 2012). Problems persisted after opening, with many customer orders from institutional and retail buyers unfilled for hours or never filled at all, while others ended up buying more shares than they had intended (McLaughlin 2012, Strasburg and Bunge 2012). This incredible gaffe, which some estimates say cost traders USD 100 million, eclipsed NASDAQ's achievement in getting Facebook's initial IPO, the third largest IPO in U.S. history. This incident has been estimated to have cost investors USD 100 million.

Another instance occurred on May 6, 2010, when U.S. financial markets were surprised by what has been referred to ever since as the "Flash Crash" Within less than 30 minutes, the main U.S. stock markets experienced the single largest price declines within a day, with a decline of more than $5 \%$ for many U.S.-based equity products. In addition, the Dow Jones Industrial Average (DJIA), at its lowest point that day, fell by nearly 1,000 points, although it was followed by a rapid rebound (Patterson 2012). This brief period of extreme intraday volatility demonstrated the weakness of the structure and stability of U.S. financial markets, as well as the opportunities for volatility-focused HFT traders (Creswell 2010). Although a subsequent investigation by the SEC cleared high-frequency traders of directly having caused the Flash Crash, they were still blamed for exaggerating market volatility, withdrawing liquidity for many U.S.-based equities (Lewis 2014).

Since the mid-2000s, the average trade size in the U.S. stock market had plummeted, the markets had fragmented, and the gap in time between the public view of the markets and the view of high-frequency traders had widened. The rise of high-frequency trading had been accompanied also by a rise in stock market volatility-over and above the turmoil caused by the 2008 financial crisis. The price volatility within each trading day in the U.S. stock market between 2010 and 2013 was nearly 40 percent higher than the volatility between 2004 and 2006, for instance. There were days in 2011 in which volatility was higher than in the most volatile days of the dot-com bubble.

Author Michael Lewis (2014, p. 59) in The Flash Boys: A Wall Street Revolt.

Although these different incidents have different causes, the effects were similar and some common conclusions can be drawn. The presence of algorithmic trading and HFT in the financial markets exacerbates the adverse impacts of trading-related mistakes. It may lead to extremely higher market volatility and surprises about suddenly-diminished liquidity. This raises concerns about the stability and health of the financial markets for regulators.

With the continuous and fast development of HFT, larger and larger shares of equity trades were created in the U.S. financial markets, as we noted earlier. Also, there was 
mounting evidence of disturbed market stability and caused significant financial losses due to HFT-related errors. This led the regulators to increase their attention and effort to provide the exchanges and traders with guidance on HFT practices They also expressed concerns about high-frequency traders extracting profit at the costs of traditional investors and even manipulating the market. Some forms of misconduct by these traders have been reported (Biais \& Woolley 2011). For instance, high-frequency traders can generate a large amount of orders within microseconds to exacerbate a trend. Other types of misconduct include: ping orders, which is using some orders to detect other hidden orders; and quote stuffing, which is issuing a large number of orders to create uncertainty in the market. HFT creates room for these kinds of market abuses, and its blazing speed and huge trade volumes make their detection difficult for regulators (Nelson \& Cox 2013).

In addition to supporting studies of HFT's impact on financial markets, such as Brogaard et al. (2014), Hendershott et al. (2011), Zhang (2010), and Jarrow and Protter (2012), regulators have taken steps to increase their regulatory authority over HFT activities. Some of the problems that arose in the mid-2000s led to regulatory hearings in the United States Senate (2009) on dark pools, flash orders and HFT practices in 2009, and the discussions continued into 2012 (Brooks 2012). Another example occurred after the Facebook IPO problem. This led the SEC to call for a limit up-limit down mechanism at the exchanges to prevent trades in individual securities from occurring outside of a specified price range so that market volatility will be under better control (Pisani 2013). These regulatory actions put stricter requirements on HFT practices, aiming to minimize the market disturbance when many fast trading orders occur within a day. Similar regulatory actions have occurred in Europe as well. For example, in September 2013, Italy became the first country to levy fees HFT trading to discourage its usage (Stafford 2013).

There is no doubt that regulations need to be properly used to guide and regulate HFT behavior. The reality, however, is a little different: regulators in different countries have not achieved a global consensus on what actually constitutes effective HFT regulatory oversight. We have observed different levels of HFT regulations across the world. Financial markets in the European Union have the strictest ones, while the United States and Canada are operating at similar levels. Other countries in the Asia Pacific region have tended to be less rigorous, so that HFT in some countries has been able to grow with few constraints - although this is certainly not true for Hong Kong. In fact, during our work on this research, we observed that many countries in Asia have set regulations to make the trading environment more HFT-friendly, rather than limit its usage. Although avoiding the negative impacts of HFT and maintaining the financial market integrity in their respective jurisdictions should be always in the mind of regulators, in Asian financial markets such as Japan, Hong Kong, Australia and Singapore, regulators have been trying to boost HFT growth for enhancing liquidity, but only within an acceptable "safety zone."

We next discuss some of the HFT-related regulations that are present in several different Asia Pacific region countries.

Japan. As the leading venue for HFT in the Asia Pacific region, Japan has been working to create a positive regulatory and technology infrastructure environment to support HFT practices, so that it can attract capital and improve liquidity (Bell 2014). For instance, in 2012, Japan announced to remove the so-called " $5 \%$ rule," so that trading volumes on its alternative trading venues no longer an upper limit (Himaras 2012). 
This action makes arbitrage easier, and the Japan financial markets became more attractive to high-frequency traders as a result.

Singapore. This is another country where the regulatory environment is becoming favorable to high-frequency traders. In order to boost its trading volume and attract more liquidity, the SGX has recently considered several regulatory changes to support HFT activities to a greater extent. We noted such adjustments as offering rebates of ownership transfer fees and liquidity provisions to HFT traders. The rationale behind these moves is to attract larger trading flows so that it can enhance the exchange's profitability (Kazmi 2012, Lim 2013).

Australia. Australia's financial markets have been relatively slow to embrace the HFT. The country's main financial regulator, Australian Securities and Investments Commission (ASIC), has been keen to act as a macro-level guide and give the market a more balanced approach to HFT. In a recent announcement, the authority released eight new rules for participants on dark liquidity and HFT (Australian Securities and Investments Commission 2013). For example, from November 2013 on, if any suspicious activity is identified in a crossing system, ASIC requires that it must be reported. The new rules provide more market transparency, diminish the likelihood of trading irregularities, and cleaner market operations.

Hong Kong. The Securities and Futures Commission (SFC) is the regulatory body set up to regulate Hong Kong's securities and futures markets. In an effort to ensure the integrity of Hong Kong's financial markets, the SFC decided to enhance its "Code of Conduct for Persons Licensed by or Registered with the Securities and Futures Commission." This applies to intermediaries and investment fund managers. To have a better risk management and market control, the SFC also introduced new regulations governing the use of trading algorithms since January 1, 2014 (Carnachan 2013). One trading rule of the SFC, however, was quite surprising: the market participants, especially the sellers and buyers, must conduct due diligence checks on each other for the use of electronic trading tools (Markets Media 2013). This rule was criticized though: it may introduce an undesirable level of uncertainty into the market.

\section{Research directions}

The range of issues on the development, evolution, impact, and risk management related to HFT deserve closer scrutiny. In what follows, we will lay out a research agenda that we hope will inspire future research in this area. The issues that we identified include: HFT technology enhancement, innovation, diffusion, and globalization; the impact and market transformation power of HFT, as well as risk management and mitigation in financial markets operations; and firm strategy and regulation that have the potential to guide and reshape the financial markets in appropriate ways. See, for example, Chakraborty (2012), who comments on appropriate regulation in this area. Appendix: Table 5 provides an overview.

We begin by offering the first research direction:

- Research Direction 1 (HFT Technology Enhancement, Innovation, Diffusion, and Globalization). There is a need to pursue new bases for enhancement and innovation related to HFT technology, and also a need to understand its patterns of diffusion and evolution in the financial markets. This will be a fruitful research 
direction when we consider the globalization of financial markets, so practical lessons and experience, together with new theory-based technology diffusion models, should be developed to provide wise guidance for future HFT functionality.

Technology improvement is a never-ending process. Even though HFT firms are able to trade at about $98 \%$ of the speed of light today, there are still incentives and room to improve and achieve faster speeds. A tiny difference in speed, measured in milliseconds of advantage in order execution, can bring potential benefits to the trader by millions of dollars. With such a large monetary incentive, HFT traders are likely to keep investing to make marginal improvements in speed, if profitability merits spending money to achieve better performance. In the future arms race, the physical speed associated with how fast an order can be sent in or cancelled, and how close the trader's server is located to the system, are not the only things that will affect the competition. Technological advances have enabled other kinds of innovative ideas in this race too. For example, the emergence and development of social media, such as Facebook and Twitter, offer opportunities for fast information access to social sentiment data (Brokaw 2012). This has the potential to be used by high-frequency traders to automatically incorporate live news into their trading strategies, so they can leverage faster information acquisition to make the appropriate decisions. Consequently, it may be also interesting for researchers to examine the value of offering real-time data services to traders, which in turn could enable new types of business models for financial services market data.

The business value of HFT innovations may take a while to be fully understood and utilized effectively, but they will continue to come to the market. As a disruptive technology innovation, HFT has demonstrated the huge value it offers, but at the same time, there also is great potential for damage to market quality, but this also will not stop its diffusion. It will be beneficial for academic researchers to apply various technology adoption and innovation diffusion models to analyze and forecast the evolutionary pattern of HFT, thus giving HFT practitioners useful guidance. One path forward for this kind of research is to look at HFT development in different regions. The U.S. and European markets, in terms of their experience with HFT operations, have been ahead of the Asia Pacific market. The more advanced markets have started to realize the positive and negative aspects of HFT activities, and have sought more balanced development, and not just higher speed for HFT practices.

The Asian markets, on the other hand, are in a relatively early stage, in which most of the effort has gone toward encouraging and fostering the adoption of HFT, and where its benefits will arise. With the increasingly integrated financial markets and globalization of national economies, the depth of experience and hard lessons from earlier HFT practices in U.S. and Europe will be valuable to support rapid learning in the Asian regional markets. This leads to our second research direction:

- Research Direction 2 (Market Impact and Transformation, and Risk Management for HFT Operations). An important research direction to pursue involves developing comprehensive methodologies, including theoretical models, empirical studies and real-world case studies. These things will enable a thorough examination of how HFT has transformed the financial markets. In particular, research should be conducted to study risk management and risk mitigation issues to improve support for HFT practices in trading operations. 
Existing research, especially the quantitative and empirical studies in Finance, have mostly emphasized the positive impacts of HFT. They have shown the different ways how HFT improves market quality by reducing bid-ask spreads, speeding up the price discovery process, and enhancing liquidity (Hendershott et al. 2011, Hendershott \& Riordan 2013). They claim not to have identified a relationship between HFT use and market volatility though (Chaboud et al. 2014). In addition, they report that the adverse impacts of HFT practices seem to be limited to traditional traders, leading to perceptions that the market is no longer a fair playing field.

On the other hand, real-world case studies have reported significant negative influences from HFT. For example, the problems with the Facebook IPO of stock on NASDAQ and the May 2010 Flash Crash created enormous chaos and economics losses, diminishing public trust in the stability of American financial markets. Why has there been such a big discrepancy between the conclusions from research and observations from practice? The time has come to re-think and examine the impact of HFT from a broader perspective. Researchers must realize that the changes caused by HFT are deeper than what is suggested by quantitative market quality measurements. They need to go beyond conventional spreads and volatility measurements that have been used in the Finance literature for a long time.

More importantly, HFT practices fundamentally influence and change how the market mechanism operates. They change how traders acquire actionable information, implement their trading strategies, and automatically submit and cancel orders. HFT also affects how exchanges have been redeveloping the technical infrastructures of their trading platforms, and exploring the adoption of different fees. The impacts of such market mechanism changes cannot be fully captured by or understood in terms of spread or liquidity measurements, though these measurements will reflect some of the changes to some extent. Recognizing this is important, because it suggests that future research needs to be conducted in a more comprehensive way from a broader perspective, using a combination of quantitative and qualitative methodologies.

Consequently, one natural research direction should involve risk management and mitigation in the financial markets. There are different types of risk related to the use of HFT approaches. First, there is operational risk coming from the reliability of trading algorithms used by HFT firms. This kind of risk always naturally exists for any kind of new technology: it can only be reduced but never eliminated. The minimization of operational risk relies on high-frequency traders' constant checking and testing of their algorithms, the use of appropriate risk management tools, and adoption of effective risk management strategies. In addition, the improper behavior of high-frequency traders will result in human-centric risk. The misconduct of traders, involving ping orders, quote stuffing and layering, for example, disturbs the effective daily operations of financial markets and impairs the ability of all of the market participants to benefit from trading. These kinds of behavior and their prevention are of interest to psychology and behavioral science researchers, as well as policy-makers.

Finally, HFT practices create systemic risk. HFT firms seem to compete among themselves and operate with limited diversity. In the race for speed, they tend to converge on the application of relatively similar algorithms and adopt similar strategies, such as colocation and data integration using social media. With such a large number of market 
participants all utilizing the same technologies and strategies, there is an obvious mechanism for systemic risk to be created. Once one mistake occurs, traders will react in the same way and respond by taking similar actions. This will amplify the negative consequence of the mistake, especially in high stress situations. This occurred during the Flash Crash happened. Many HFT firms simultaneously tried to withdraw from the market, which caused illiquidity for the trade of various equities. How to control systemic risk and prevent the crash of the whole financial market is a critically important topic, especially to regulators. This prompts our third research direction:

- Research Direction 3 (Firm Strategy, Regulation, and Future Opportunities for HFT). Huge first-mover advantage has existed for HFT firms, but such advantage has been disappearing quickly in the presence of intense competition. HFT firms will need to explore new marketplaces and look for fresh arbitrage opportunities globally. In addition, how to make use of the power of regulation to guide an appropriate level of HFT activities in financial markets is of sentinel interest for effective government oversight.

Another research direction that we suggest is to analyze HFT practices using an ecosystem view, instead of as an isolated technological innovation. This requires a systematic and integrated research perspective that includes all the participants in the financial markets, including high-frequency traders, conventional traders, software algorithm vendors, technology and platform infrastructure providers, stock exchanges, and regulators. The reason for employing an ecosystem view is simple: since the use of HFT impacts all market participants and the market itself as a whole, the actions, decisions, and strategies of these participants will influence how HFT practices evolve over time.

For example, as we have discussed, competition among firms has been a major driver for HFT development. High-frequency traders compete on the basis of speed and improved trading strategies to achieve higher returns, the impetus for continuing technology innovation in the financial markets. The winners in this arms race typically are those who can trade faster than their competitors or who are using more advanced trading algorithms, and processing the information that they receive in ways that are different from the market.

The high returns of the first-movers in HFT markets are not sustainable though, like in ther financial services settings (Tufano 1989). With appropriate quantitative modeling and technical staff, who can be readily acquired in the labor market, competitors can imitate the firms that are succeeding, and transform the technological advantages of the leaders into market-wide competitive necessities. Intense competition has pushed many HFT firms to go to great lengths to gain an edge. Their actions have included: searching for and hiring top computer scientists to develop fast algorithms; trimming fractions of seconds off trading times by physically moving their computer servers to be co-located with the data processing facilities of the stock exchanges where they trade. These things are very expensive for the HFT firms. As a result, the profits of HFT firms are reported to have declined since the financial crisis of 2008 (Phillips 2013). First-mover advantage appears to have quickly diminished for HFT firms.

Beyond continuous technological innovation and efforts to compete in the financial markets, another strategy for HFT firms may be to enter new financial markets where arbitrage opportunities have not yet been fully explored. In recent years, HFT has been growing around the world, but not all regions have demonstrated growth at the same 
pace. The development of HFT in major Asian financial markets is still in its initial stage, and some of the market environments are friendly and supportive relative to U.S. and Europe markets, and are worthwhile for firms to patiently explore. Many Asian countries welcome HFT practices because they believe such approaches to trading will help to attract liquidity and support further development of local financial markets. In addition, there are still some regions that have not experienced HFT trader entry to any great extent. This includes the huge financial markets of China. Thus, we expect to see more HFT firms starting to show an interest in the Asian Pacific region, as they search for fresh opportunities.

Other important stakeholders in the HFT technology ecosystem are the regulators. They have the power to set rules and laws to guide the development of HFT practices. Their actions will directly or indirectly support or restrict the adoption and development of HFT in different national economies. U.S. and E.U. policy-makers, it seems, have been mostly taking a trial-and-error approach. They learn from errors and failures, and then revise the existing regulations accordingly to solve the specific problems they have seen. This process also involves repetition, with the hope that what will eventually result will converge to the most appropriate set of financial regulations.

Some examples will help to illustrate this point. One occurred after the early emergence of computerized trading and ECNs in late 1990s. The U.S. stock exchanges revised their price quotation rules in 2001 to allow trade to be priced in decimals, which encouraged algorithm trades via the ECNs. In the following several years from 2001 to 2012, algorithmic trading grew rapidly. This showed the regulatory concerns about the over-heated growth of algorithmic trading activities. Following the chaos of NASDAQ's problems with Facebook's IPO in May 2012 and Knight Capital's failure in August 2012, the U.S. Federal Bureau of Investigation (FBI) started to investigate the role of social media in securities fraud in November 2012 (Goldstein \& Ablan 2012). The Securities and Exchange Commission (2013) laid out new restrictions on the use of social media behavior related to public company announcements in 2013. From these past cases, we are able to observe the relationship between regulation and financial market operations, and their mutual actions and reactions.

Financial market policy-makers in the Asia Pacific region have the advantage of making use of the pioneering experiences of regulators in other parts of the world, so they do not make the same mistake. This is the benefit of being a step slower than their counterparts in the U.S. and Europe in terms of HFT development: they can use a learning-by-doing process instead of a trial-and-error approach. In the future, they also will need to pay attention to key issues such as risk management, trading algorithm reliability, platform robustness, trading strategies and record tracking, and market transparency. They also need to explore how to minimize perceptions about and the reality of unfair advantage for some traders. When the speed advantage of HFT market participants puts the fairness and integrity of the market at risk, investor confidence will erode, and in the long run, may result in their reluctance to participate. These issues will be valuable to examine more closely.

\section{Conclusion}

High-frequency trading (HFT) capabilities represent a European and American financial innovation that has developed and diffused rapidly around the world. Today, HFT market participants generate nearly half of the trading activities in U.S. financial 
markets. As HFT firms from the U.S. and U.K. have expanded their global influence, major financial markets in other regions have all been penetrated by HFT. The continental European Community countries are the most prominent adopters of HFT practices outside the U.S. and the U.K. now. The financial markets in European Community have demonstrated a similar HFT adoption trend as in the American and London markets, with about $25 \%$ of equity trading volume attributed to HFT activities.

Compared with financial markets in U.S. and European Community, financial markets in the Asia Pacific region have been a little slower to buy into HFT adoption. However, the major Asian markets are all moving towards greater efficiency by exploring how they can best employ more HFT. To support HFT practices, the exchanges in the Asia Pacific region have to upgrade their trading infrastructures, set up new trading and pricing rules, and enhance their capability to handle large volumes of trades very fast. This will permit them to effectively compete for market share and establish greater liquidity in their respective markets.

When all of the global markets have been penetrated by HFT practices, effective cooperation among a group of key stakeholders, including the exchanges, technology providers, third-party software vendors, and traders, is likely to be a pre-condition for exchange operations around the world. Some examples are the TSE's merger with OSE in Japan and NYSE Euronext's effort to merge with the Deutsche Boerse.

In this study in mid-2015, we did not find sufficient evidence to suggest that HFT practices have created dramatic new and strong forces to transform the regional markets of the Asia Pacific region. In fact, we found that there has been a mixed response to the implementation of HFT among financial markets here. Japan and Australia have truly embraced HFT practices, by making the kinds of technology investments, and adjusting trading regulations and fee structures that make their financial markets more conducive to HFT activities than in the past. HFT traders are still few in number, and not generating the aggregate volume and value of HFT trades in the Hong Kong and Singapore stock exchanges, as can be observed elsewhere. This is mainly due to the high transaction costs and lack of market fragmentation that might support arbitrage for domestic equity trading in these two markets.

HFT is embraced in these financial markets. It serves to diminish the bid-ask spreads and reduce transaction costs for all market participants. It also typically contributes to higher market liquidity (though not all observers agree with this), and a faster price discovery process. Despite these apparent benefits, the countervailing down-side impacts have caught the attention of regulators, investors, media analysts, and academic researchers. They have all observed and analyzed the market failures and trading accidents that have occurred in recent years - all apparently having some ties to HFT practices. These incidents have all been front-page news in the digital financial newspapers of our time: the Flash Crash, the Facebook IPO, and Knight Capital's software glitch in the U.S., and the Everbright Securities episode in China. These accidents exposed the weakness and vulnerability of current financial markets, suggesting that proper regulations must be implemented to guide and limit the behavior of high-frequency traders.

\section{Endnotes}

${ }^{1}$ The journalist, Michael Lewis (2014), in his book The Flash Boys: A Wall Street Revolt, reported on the race to reduce the latency of sending buy and sell orders to the 
market through different means, including constructing a dedicated low-latency line to create the "shortest and straightest" route from Chicago to New York. This was to reduce the round-trip communication time between these points from 13.10 milliseconds to 12.98 milliseconds (Spread Networks 2012), creating fast network advantage, and improving performance over a typical network that can deliver round-trip performance in 14.5 milliseconds (Adler 2012).

${ }^{2}$ There are numerous sources of HFT value and market share data. In this article, we will refrain from presenting data on estimated values for these facts, which will cause some of the numbers that we report to not be as current as is sometimes seen in what the press reports.

${ }^{3} \mathrm{An}$ interesting footnote to the Flash Crash is that the investigation is continuing as of April 2015 (Goodley 2015). A British trader operating from a suburban house in Hounslow, West London, is alleged to have placed "multiple, simultaneous, large-volume sell orders at different price points - a technique known as 'layering' ... [this] created the appearance of substantial supply in the market ... When prices fell as a result of this activity, [the trader] allegedly sold futures contracts only to buy them back at a lower price."

\section{Appendix}

Table 3 Definitions of Key Terms and Concepts

\begin{tabular}{|c|c|c|}
\hline Terms & Definitions & Comments \\
\hline $\begin{array}{l}\text { Algorithmic } \\
\text { Trading }\end{array}$ & $\begin{array}{l}\text { Use of an electronic platform for entering } \\
\text { trading orders with an algorithm that } \\
\text { executes programmed trading instructions } \\
\text { based on timing, price and volume. }\end{array}$ & $\begin{array}{l}\text { Used by buy-side traders, such as mutual } \\
\text { funds, pension funds and investment banks, } \\
\text { whose customers need sophisticated market } \\
\text { support services. }\end{array}$ \\
\hline $\begin{array}{l}\text { Alternative } \\
\text { Trading Systems }\end{array}$ & $\begin{array}{l}\text { Non-exchange trading platforms that match } \\
\text { buy orders and sell orders. }\end{array}$ & $\begin{array}{l}\text { Account for a lot of liquidity trading; Dark pools } \\
\text { and ECNs are alternative trading systems. }\end{array}$ \\
\hline Bid-Ask Spread & $\begin{array}{l}\text { Difference between highest price a buyer is } \\
\text { willing to pay and lowest price a seller is } \\
\text { willing to sell an asset. }\end{array}$ & $\begin{array}{l}\text { If the bid price is } \$ 40 \text { and the ask price is } \\
\$ 41 \text {, then the bid-ask spread is } \$ 1 \text {. }\end{array}$ \\
\hline Circuit Breaker & $\begin{array}{l}\text { Defensive approach used by exchanges to } \\
\text { limit damage induced by the sharply fall of a } \\
\text { security's price. }\end{array}$ & $\begin{array}{l}\text { Activated when a market index falls by a } \\
\text { predeter-mined amount in a period of time, } \\
\text { so trading stops. }\end{array}$ \\
\hline Co-locationService & $\begin{array}{l}\text { High-frequency traders place trading } \\
\text { computers in data centers that house } \\
\text { exchange's computer servers. }\end{array}$ & $\begin{array}{l}\text { Made available by stock exchanges, which } \\
\text { charge fees for services offered, building new } \\
\text { revenues. }\end{array}$ \\
\hline Dark Pool & $\begin{array}{l}\text { A private space for institutional investors to trade } \\
\text { away from the public exchanges, which enables } \\
\text { them to maintain secrecy about potentially large } \\
\text { lots of stick that are to be traded. }\end{array}$ & $\begin{array}{l}\text { Trades that happen in dark pools are } \\
\text { concealed from the public. These occur due } \\
\text { to the fragmentation of the financial markets, } \\
\text { and because electronic trading enables them. }\end{array}$ \\
\hline Decimalization & $\begin{array}{l}\text { System that requires the prices of securities } \\
\text { to be quoted in decimals rather than in a } \\
\text { fractional format. }\end{array}$ & Helps to narrow the bid-ask spread. \\
\hline $\begin{array}{l}\text { Electronic } \\
\text { Communication } \\
\text { Network }\end{array}$ & $\begin{array}{l}\text { An ECN is an automated system to match } \\
\text { buy and sell orders for securities, typically } \\
\text { after an exchange's regular operating hours. }\end{array}$ & $\begin{array}{l}\text { Allows brokerages to trade directly with } \\
\text { individual investors without a middleman; } \\
\text { supports investors across different regions }\end{array}$ \\
\hline Front-Running & $\begin{array}{l}\text { An illegal practice in which brokers trade for } \\
\text { their own account ahead of their customers, } \\
\text { based on the knowledge of the pending } \\
\text { orders from them. }\end{array}$ & $\begin{array}{l}\text { When pending orders from customers are } \\
\text { predicted to influence the security price, } \\
\text { trading ahead of customers allows brokers to } \\
\text { obtain more profit. }\end{array}$ \\
\hline Layering & $\begin{array}{l}\text { A strategy used by HFT brokerage firms that } \\
\text { enter and cancel orders that they never truly } \\
\text { intend to execute quickly. }\end{array}$ & $\begin{array}{l}\text { Involves ask orders above the market price, } \\
\text { followed by bid orders that approach that } \\
\text { price by HFT firms; bids are canceled once } \\
\text { the higher price is reached. Recognized as } \\
\text { market manipulation. }\end{array}$ \\
\hline
\end{tabular}


Table 3 Definitions of Key Terms and Concepts (Continued)

\begin{tabular}{|c|c|c|}
\hline Liquidity & $\begin{array}{l}\text { Traders can buy / sell securities in market } \\
\text { without creating an impact on securities' } \\
\text { prices. }\end{array}$ & $\begin{array}{l}\text { Liquidity implies low transaction cost, the } \\
\text { possibility of immediate trades, and deep } \\
\text { demand / supply. }\end{array}$ \\
\hline Ping Orders & $\begin{array}{l}\text { Using small equity orders to detect other } \\
\text { hidden trade orders. }\end{array}$ & $\begin{array}{l}\text { Used to detect hidden supply / demand in } \\
\text { dark pools. }\end{array}$ \\
\hline Price Discovery & $\begin{array}{l}\text { The process of determining an equity's price } \\
\text { in a financial market through interactions } \\
\text { between sellers and buyers. }\end{array}$ & $\begin{array}{l}\text { The price discovery process is influenced by } \\
\text { many factors that affect market demand and } \\
\text { market supply. }\end{array}$ \\
\hline Quote Stuffing & $\begin{array}{l}\text { Practice of HFT firms that enter and withdraw } \\
\text { orders quickly to increase market uncertainty } \\
\text { to create trading opportunities. }\end{array}$ & $\begin{array}{l}\text { Larger players (market-makers), are able to } \\
\text { do this practice, because they have direct } \\
\text { links to stock exchanges. }\end{array}$ \\
\hline Regulation NMS & $\begin{array}{l}\text { Regulations to promote the development of } \\
\text { a national market system in the U.S. for } \\
\text { equity trading. }\end{array}$ & $\begin{array}{l}\text { Focused on immediate priority for inter- } \\
\text { market equity prices, fast access to quotes, } \\
\text { and minimum stock price increments. Similar } \\
\text { to MiFID rules in Europe. }\end{array}$ \\
\hline Stamp Duty & $\begin{array}{l}\text { A tax levied on legal documents that are } \\
\text { filed when economic transactions occur. }\end{array}$ & $\begin{array}{l}\text { Usually involve the ownership transfer of } \\
\text { assets or property for stocks, bonds and } \\
\text { other financial instruments. }\end{array}$ \\
\hline $\mathrm{T}+1$ Regulation & $\begin{array}{l}\text { Stocks are not allowed to be sold on the day } \\
\text { when they are bought, but only the following } \\
\text { day }-T+1 \text {. }\end{array}$ & Adopted by stock exchanges in China. \\
\hline Tick Size & $\begin{array}{l}\text { The minimum price increment for securities } \\
\text { price quotes. }\end{array}$ & Tick sizes can be fixed or flexible. \\
\hline Volatility & $\begin{array}{l}\text { Used to measure dispersion or variance of a } \\
\text { security's price. }\end{array}$ & $\begin{array}{l}\text { Indicates uncertainty about changing prices } \\
\text { of a security. }\end{array}$ \\
\hline
\end{tabular}

Table 4 Accelerators and Decelerators for HFT Adoption in the Asian Countries

\begin{tabular}{|c|c|c|}
\hline Location & Accelerating Factors & Decelerating Factors \\
\hline Japan & $\begin{array}{l}\text { Arrowhead launch at Tokyo Stock Exchange; } \\
\text { low transaction fees, with average cost of } 18.34 \\
\text { basis points in 2010; high fragmentation level } \\
\text { for trading of equities; very small tick size; } \\
\text { favorable regulations (Yoon 2010). }\end{array}$ & None \\
\hline Australia & $\begin{array}{l}\text { Trading infrastructure recently upgraded; co- } \\
\text { location services available; low trading fees at } 15 \\
\text { basis points; Chi-X uses maker-taker pricing } \\
\text { model (Mishkin 2011). }\end{array}$ & $\begin{array}{l}\text { Low fragmentation level with only three } \\
\text { exchanges in Australia's market; and no } \\
\text { transaction rebates (Securities and Exchange } \\
\text { Commission 2010). }\end{array}$ \\
\hline $\begin{array}{l}\text { Hong } \\
\text { Kong }\end{array}$ & $\begin{array}{l}\text { Automated Order Matching and Execution } \\
\text { System (AMS/4) upgraded in } 2011 \text { (Aite Group } \\
\text { 2011). }\end{array}$ & $\begin{array}{l}\text { High stamp duty of } 0.1 \% \text { tax for ownership } \\
\text { transfer of equity shares; low fragmentation level } \\
\text { for individual equity grading; and an unfavourable } \\
\text { regulatory environment (Gov.HK 2013). }\end{array}$ \\
\hline Singapore & $\begin{array}{l}\text { Launch of ultra-fast trading engine, SGX Reach; } \\
\text { co-location service; deployment of circuit breakers } \\
\text { and risk controls as new market safeguards; pro- } \\
\text { posed regulatory changes include offering rebates } \\
\text { for ownership transfer fees and provision of } \\
\text { liquidity to HFT traders (Malakian 2011). }\end{array}$ & $\begin{array}{l}\text { High trading fees at } 20 \text { basis points; no market } \\
\text { fragmentation with just SGX; new rules to } \\
\text { regulate HFT operations in dark pools (Gov.HK } \\
\text { 2013). }\end{array}$ \\
\hline China & $\begin{array}{l}\text { Introduction of low-latency trading technology } \\
\text { (Grant 2012). }\end{array}$ & $\begin{array}{l}\text { Unfavorable regulatory environment; high } \\
\text { network communication latency; T+ } 1 \\
\text { regulation; low-level IT support; high stamp duty } \\
\text { (Grant 2012). }\end{array}$ \\
\hline $\begin{array}{l}\text { South } \\
\text { Korea }\end{array}$ & $\begin{array}{l}\text { South Korea seems to lack basic accelerators for } \\
\text { HFT trading to take hold and flourish (Kang 2012). }\end{array}$ & $\begin{array}{l}\text { Implementation of a kill switch for trading (Song } \\
\text { \& Grant 2013); little investment in sophisticated } \\
\text { trading technology and hardware infrastructure } \\
\text { (Kang 2012); fees for equity trading (Barnes 2013). }\end{array}$ \\
\hline
\end{tabular}


Table 4 Accelerators and Decelerators for HFT Adoption in the Asian Countries (Continued)

\begin{tabular}{|c|c|c|}
\hline India & $\begin{array}{l}\text { Launch of co-location service in } 2010 \text {; direct } \\
\text { market access available; approval of smart order } \\
\text { routing in BSE; BSE reduced fees (The Trading } \\
\text { Mesh } 2011 \text { b, NSE 2014). }\end{array}$ & $\begin{array}{l}\text { Low matching engine speed; low fragmentation } \\
\text { level; NSE has high clearing and trading fees } \\
\text { (The Trading Mesh } 2011 \text { b); sometimes lacking } \\
\text { liquidity in market to close out positions. }\end{array}$ \\
\hline Indonesia & $\begin{array}{l}\text { Direct market access available (Valentine \& Misra } \\
\text { 2012). }\end{array}$ & $\begin{array}{l}\text { Low fragmentation level with only one } \\
\text { exchange: Indonesia Stock Exchange. }\end{array}$ \\
\hline Thailand & $\begin{array}{l}\text { Direct market access available; trading platform } \\
\text { technology upgraded; tick size reduced } \\
\text { (Valentine \& Misra 2012). }\end{array}$ & $\begin{array}{l}\text { Low fragmentation level with only two stock } \\
\text { exchanges: Stock Exchange of Thailand and } \\
\text { Market for Alternative Investment. }\end{array}$ \\
\hline Malaysia & $\begin{array}{l}\text { Direct market access available; platform } \\
\text { technology upgraded; tick size reduced } \\
\text { (Valentine \& Misra 2012). }\end{array}$ & $\begin{array}{l}\text { Low fragmentation level, with only one } \\
\text { exchange; infrastructure is still too young for } \\
\text { HFT development (Lim 2014). }\end{array}$ \\
\hline Philippines & $\begin{array}{l}\text { Platform technology upgraded; tick size reduced } \\
\text { (Valentine \& Misra 2012); implmenention of } \\
\text { broker anonymity (Valentino 2014). }\end{array}$ & $\begin{array}{l}\text { Low fragmentation level with only one } \\
\text { exchange: Philippine Stock Exchange. }\end{array}$ \\
\hline $\begin{array}{l}\text { New } \\
\text { Zealand }\end{array}$ & Favorable regulatory environment (Lynch 2013). & $\begin{array}{l}\text { Low trading volume; no co-location service } \\
\text { (Field 2014). }\end{array}$ \\
\hline
\end{tabular}

Table 5 Directions for Future Research

\begin{tabular}{|c|c|c|c|}
\hline $\begin{array}{l}\text { Research } \\
\text { Directions }\end{array}$ & Research Questions & Theories and Approaches & Potential Contributions \\
\hline $\begin{array}{l}\text { HFT technology } \\
\text { enhancement, } \\
\text { innovation, } \\
\text { diffusion and } \\
\text { globalization }\end{array}$ & $\begin{array}{l}\text { - What is the business value } \\
\text { of advanced technology, } \\
\text { such as real-time data } \\
\text { services for traders? } \\
\text { - What about HFT } \\
\text { innovations? } \\
\text { - What can Asian financial } \\
\text { markets learn from U.S. and } \\
\text { Europe? }\end{array}$ & $\begin{array}{l}\text { Digital divide theory; } \\
\text { technology adoption and } \\
\text { diffusion theory; event } \\
\text { history methods for } \\
\text { adoption events; finite } \\
\text { mixture logit modeling. }\end{array}$ & $\begin{array}{l}\text { Based on technology and } \\
\text { innovation adoption and } \\
\text { diffusion models, we can } \\
\text { analyse and forecast the } \\
\text { evolutionary patterns of HFT } \\
\text { in emerging markets, such as } \\
\text { Asian financial markets in } \\
\text { Asian, and give HFT } \\
\text { practitioners useful guidance } \\
\text { and help them avoid some } \\
\text { problems. }\end{array}$ \\
\hline
\end{tabular}

Market impact, transformation, and risk management for HFT operations

\section{- What's the impact of HFT} on the underlying market quality?

- How are retail and institutional investors influenced by HFT use?

- Why do significant incidents, such as the Flash Crash, happen in financial markets that employ HFT practices?

- How to manage and mitigate risks, such as operational risk and traders' misconduct, in financial markets with HFT present?

Firm strategy, regulation, and future opportunities for HFT
- How will actions, decisions and strategies of market participants influence the evolution of HFT?

- How do HFT regulations differ around the world?

- What effects will they have on HFT evolution?

- How can regulators ensure the fairness and integrity of financial markets with HFT present?
Microeconometrics and empirical methods; natural experiments; and matched sample designs.

Theories of firm competition and strategy; financial IS ecosystem approach.
Researchers need to take a broader perspective than traditional bid-ask spread and liquidity measurement, to analyze the impact of HFT on financial markets. Researchers also should provide suggestions on the control of risks in the presence of HFT presence and promote market stability.

By studying financial markets with HFT practices, researchers can develop a deeper understanding of their impacts on different kinds of stakeholders. Also, the roles of regulators in promoting market-wide fairness and integrity need to more fully understood. 


\section{Competing interests.}

The authors declare that they have no competing interests.

\section{Authors' contributions}

RK initiated this project, and conceptualized the contents of the research. RK, YH and DM have: made substantial contributions to the research and analysis in this research; and been involved in drafting the manuscript for important intellectual content. All authors read and approved the final manuscript.

\section{Acknowledgments}

The authors would like to thank the following individuals for helpful comments on the contents of this article and related research: Leon Zhao, Zhang Zhongyi, Liu Jun, and Guo Zhiling, as well as the anonymous reviewers. An early version of some elements of this research was discussed in a presentation at the $1^{\text {st }}$ Workshop on Internet and Big Data Finance (WIBF), which was held at City University of Hong Kong on June 7, 2014. Rob Kauffman appreciates the financial support offered by Southwestern University of Finance and Economics. Hu Yuzhou thanks Singapore Management University for doctoral fellowship support. Ma Dan acknowledges the School of Information Systems for ongoing funding of her research. All opinions, errors and omissions are the sole responsibility of the authors.

\section{Received: 12 May 2015 Accepted: 12 May 2015}

Published online: 09 June 2015

\section{References}

Adler J (2012) Raging bulls: how Wall Street got addicted to light-speed trading. Wired, August 8

Agarwal A (2012) High-frequency trading: evolution and the future - how the emergence of high frequency trading is altering the financial landscape as firms look to make money on the millisecond. Technical report, Capital Markets, Cap Gemini, Paris, France

Aite Group (2011) Connecting to future opportunities: cross-border low latency connectivity. White paper, in partnership with NTT Communications, Tokyo, Japan.

Aldridge I (2013) High-frequency trading: a practical guide to algorithmic strategies and trading systems, 2nd edn. John Wiley, New York, NY

Australian Securities Exchange (2010) Market announcement: ASX fees and activity rebates. Sydney, New South Wales, Australia, June 3

Australian Securities and Investments Commission (2013) Dark liquidity and high frequency trading. Report 331 , Sydney, New South Wales, Australia, March 18

Barnes D (2013) HFT: trading - HFT on trial. Blogpost, BestExecution, London, UK, July 17

Bell H (2014) HFT regulation requires attention to motives and consequences. Tabb Forum, London, UK, May

Bershova N, Rakhlin D (2013) High-frequency trading and long-term investors: a view from the buy-side. Journal of Investment Strategies 2(2):25-69

Biais B, Woolley P (2011) High-frequency trading. Industrial Economics Institute, Toulouse University, Toulouse, France, March, Working paper

Brogaard J, Hendershott T, Riordan R (2014) High-frequency trading and price discovery. Review of Financial Studies 27(8):2267-2306

Brokaw A (2012) How Twitter is being mined to predict market-moving events. Minyanville.com, New York, NY, December 6

Brooks AM (2012) Testimony on computerized trading: what should the rules of the road be? United States Senate, Washington, DC, September 22

Brummer C (2008) Stock exchanges and the new markets for securities laws. University of Chicago Law Review 75(4):1435-1491

Bunge J (2013) Getco to close Hong Kong Office. Wall Street Journal, New York, NY, March 20. Available at: www.wsj.com/articles/SB10001424127887323419104578372902775768108

Bunge J (2014) A suspect emerges in stock-trade hiccups: Regulation NMS. Wall Street Journal, New York, NY, January 27. Available at www.wsj.com/articles/SB10001424052702303281504579219962494432336

Burgos J (2013) Singapore Exchange seeks high-frequency traders: Southeast Asia. Bloomberg, New York, NY, October 27

Byrne JA (2010) Traders thrive on live in the fast lane. Institutionallnvestor.com, November

Carnachan S (2013) Get ready to implement Hong Kong electronic trading rules. Alternative Investment Management Association, London, UK, $4^{\text {th }}$ quarter

Chaboud AP, Chiquoine B, Hjalmarsson E, Hjalmarsson E, Vega C (2014) Rise of the machines: algorithmic trading in the foreign exchange market. Journal of Finance 69(5):2045-2084

Chakraborty S (2012) High frequency trading: enforcing the right controls. White paper, Tata Consultancy Services, Mumbai, India

China Daily (2013) CSRC blames Everbright Securities for spike. Beijing, China, August 17

Chlistalla M (2011) High-frequency trading: better than its reputation? Deutsche Bank Research, Frankfurt am Main, Germany, February 7

Chordia T, Goyal A, Lehmann BN, Saar G (2013) High-frequency trading. Journal of Financial Markets 16(4):637-645

Comerton-Forde C (2012) Is Australia HFT-friendly? JASSA: The Finsia Journal of Applied Finance, 3. Sydney, New South Wales, Australia, pp 12-14

Credit Suisse (2014) NASDAQ OMX Group Inc. (NDAQ). Equity Research, Americas / United States, Credit Suisse, New York, NY, April 22

Creswell J (2010) Speedy new traders make waves far from Wall Street. New York Times, New York, NY, May 16 Field T (2014) High-volume trading causing problems on Wall Street. 3 News NZ, Auckland, NZ, April 1

Fujitsu (2010). TSE launches next-generation Arrowhead trading system. Tokyo, Japan, August 8

Goldstein M, Ablan J (2012) FBI uses Twitter, social media to look for securities fraud. Reuters, New York, NY, November 26

Gomber P, Arndt B, Lutat M, Uhle T (2011) High-frequency trading. Working paper, Faculty of Economics and Business Administration, Goethe University, Frankfurt, Germany

Goodley S (2015) U.K. trader arrested over 2010 global markets 'Flash Crash.' The Guardian, London, UK, April 22 
Gov.HK (2013) Stamp duty rates. Hong Kong, China. Available at: www.gov.hk/en/residents/taxes/stamp/ stamp_duty_rates.htm

Grant J (2011) U.S. high-frequency trading firms look eastward. Wall Street \& Technology, New York, NY, May 11 Grant J (2012) China moves to algorithmic trading. Financial Times, London, UK, August 6

Hasbrouck J, Sofianis, G, Sosebee D (1993) New York Stock Exchange systems and trading procedures. Working paper no. 93-01, New York Stock Exchange, New York, NY

Hendershott T, Jones CM, Menkveld AJ (2011) Does algorithmic trading improve liquidity? Journal of Finance 66(1):1-33

Hendershott T, Riordan R (2013) Algorithmic trading and the market for liquidity. Journal of Financial and Quantitative Analysis 48(4):1001-1024

Himaras E (2012) Japan removes 5\% takeover trigger for PTS venues. Bloomberg Business, New York, NY, October 26 Investopedia (2015) Algorithmic trading. Available at: www.investopedia.com/terms/a/algorithmictrading.asp Ito T (2013) The impact of stock price and interest rate on the REIT market in Japan. International Journal of Business 18(4):359-368

Jarrow RA, Protter P (2012) A dysfunctional role of high frequency trading in electronic markets. International Journal of Theoretical and Applied Finance 15(3)

Jaswal A (2010) Electronic trading in Asia-Pacific: a market by market update on the dynamic region. Celent, New York, NY, October 15

Kang YW (2012) Fast trading: help or hurts market? Money. The Korea Times, Seoul, South Korea, March 25 Kavesh RA, Garbade KD, Silber WL (1978) Technology, communication and the performance of financial markets: 1840-1975. Journal of Finance 33(3):819-832

Kazmi M (2012) Keeping Asian markets safe: the HFT debate. Asian Banker, Singapore, December 23

Keith C, Grody A (1988) Electronic automation at the New York Stock Exchange. In: Guile BR, Quinn JB (eds) Managing innovation: cases from the services industries. National Academy of Sciences, National Academy Press, Washington, DC, pp 82-107

Kingsley T, Phadnis K, Stone G (2013) HFT: perspectives from Asia - part I. Bloomberg Tradebook, New York, NY, June 11

Levine DM (2012) Facebook IPO mess: blame falls on high-frequency trading. Huffington Post, New York, NY, May 24 Lewis M (2014) The flash boys: a Wall Street revolt. W.W. Norton, New York, NY

Lim K (2013) SGX mulls over rebates for high-frequency market makers. The Business Times, Singapore, October 29 Lim S (2014) Is high frequency trading happening in Malaysia? Value Invest Asia, Singapore, August 18

Lynch N (2013) New Zealand regulator to push for more algorithmic trading. Asian Legal Business. Thomson Reuters, Hong Kong, China, May 28

Malakian A (2011) Some final thoughts on the launch of SGX Reach. WatersTechnology, London, UK, August 19

Markets Media (2013) Hong Kong goes electronic. New York, NY, December 3

McGowan MJ (2010) The rise of computerized high frequency trading: use and controversy. Duke Law and Technology Review 16, Chapel Hill, NC, November 8

McLaughlin T (2012) Facebook IPO glitch prompts margin calls, headaches. Reuters, New York, NY, May 25

Mehta N (2009) High-frequency trading is a tough game. Traders Magazine, SourceMedia, New York, NY, November 24 Menkveld AJ (2013) High frequency trading and the new market makers. Journal of Financial Markets 16(4):712-740

Miller M, Wildau G (2013) China vets brokerages' computer systems after \$3.8 billion buy error. Reuters, New York, NY, August 22

Mishkin S (2011) Chi-X Australia moves to undercut ASX. FT.com, London, UK, October 11

NASDAQ (2015) About NASDAQ. New York, NY, April. Available at www.nasdaq/about/about.pdf

Nelson L, Cox L (2013) HFT and the question of regulation. PriceWaterhouseCoopers, London, UK

NSE (2014) NSE trading technology. NSE, Mumbai, India

Patterson S (2012) Dark pools: high-speed traders, Al bandits, and the threat to the global financial system. Crown Business, New York, NY

Perez E (2013) Knightmare on Wall Street: the rise and fall of Knight Capital. Self-published, Edgar Perez Inc., New York, NY

Petram LO (2011) The world's first stock exchange: how the Amsterdam market for Dutch East India Company shares became a modern securities market, 1602-1700. Doctoral thesis. University of Amsterdam, Eigen Beheer, Amsterdam, Netherlands

Phillips M (2013) How the robots lost: high-frequency trading's rise and fall. Bloomberg Business, New York, NY, June 6

Pisani B (2013) New trading curbs: limit up, limit down is finally here. Trader Talk, CNBC, New York, NY, April 4

Popper N (2012a) Knight Capital says trading glitch cost it $\$ 440$ million. DealBook, New York Times, New York, NY, August 2

Popper N (2012b) High-speed trading no longer hurtling forward. New York Times, New York, NY, October 14

Popper N (2013) NASDAQ is fined $\$ 10$ million over mishandled Facebook public offering. New York Times, New York, NY, May 29

Price M (2013) Asia goes slow on high-speed trading. MoneyBeat, Wall Street Journal, New York, NY, October 7. Available at: blogs.wsj.com/moneybeat/2013/10/07/asia-goes-slow-on-high-speed-trading

Rogow, G (2012) Colocation: the root of all high-frequency trading evil? Wall Street Journal, New York, NY, September 20. Available at: blogs.wsj.com/marketbeat/2012/09/20/collocation-the-root-of-all-high-frequency-trading-evil/

Securities and Exchange Commission (1998) Regulation of exchange and alternative trading systems. Release No. 34-40760, New York, NY, December 8

Securities and Exchange Commission (2005) Regulation NMS. Release No. 34-51808, New York, NY, August 29

Securities and Exchange Commission (2010) Concept release on equity market structure; proposed rule. 75 Federal Register 3603 75(13, New York, NY, January 21

Securities and Exchange Commission (2012) Report to Congress on decimalization. Washington, DC, July

Securities and Exchange Commission (2013) SEC says social media ok for company announcements if investors are alerted. Washington, DC, April 2

Shorter G, Miller RS (2014) High-frequency trading: background, concerns, and regulatory developments. Congressional Research Service, Washington, DC, June 19 
Singapore Exchange (2012) Application of market phases and algorithm. Practice note 8.2.1, Securities Market Control, Singapore, February 17

Song JA, Grant J (2013) South Korea exchange rushes to implement 'kill switch.'. Financial Times, London, UK, December 30

Sorkin RA (2014) Fault goes deep in ultrafast trades. New York Times, New York, NY, March 31

Spread Networks (2012) Spread Networks announces Chicago-New York latency improvements - dark fiber improved to 12.98 milliseconds roundtrip, ultra low latency waves under 14.1 milliseconds. Ridgeland, MS, October 4 Stafford P (2013) Italy introduces tax on high-speed trade and equity derivatives. FT.com, London, UK, September 1 Steiner TB, Teixeira DB (1989) Technology in banking: creating value and destroying profits. Dow Jones-Irwin, Homewood, IL Stoll HR (2006) Electronic trading in stock markets. Journal of Economic Perspectives 20(1):153-174

Strasburg J, Bunge J (2012) Social network's debut on NASDAQ disrupted by technical glitches, trader confusion. Wall Street Journal, New York, NY, May 18. Available at: www.wsj.com/articles/SB100014240527023034484045774 12251723815184

Sun H (2013) Everbright reports loss after flawed trades. Bloomberg Business, New York, NY, August 18

SWIFTRef (2015) MiFID: effective since 1st of November 2007, MiFID changed the regulatory regime governing transaction reporting. Brussels, Belgium, April 27. Available at: swiftref.swift.com/mifid

Swinburne K (2010) On regulation of trading in financial instruments - 'dark pools,' etc. Report, Committee on Economic and Monetary Affairs, European Parliament, Brussels, Belgium, November 16

Tabb Forum (2014) No, Michael Lewis, the U.S. equities market is not rigged. MoneyBeat, Wall Street Journal, New York, NY, April 1. Available at: tabbforum.com/opinions/no-michael-lewis-the-us-equities-market-is-not-rigged

Tagliani M (2009) The practical guide to Wall Street: equities and derivatives. John Wiley and Sons, Hoboken, NJ

Takeo Y, Hasegawa T (2014) Japan exchange eschews smaller tick sizes for more stocks. Bloomberg Business, New York, NY, December 10

Terrell E (2012) History of the New York Stock Exchange. Business Reference Services, Science, Technology and Business Division, United States Library of Congress, Washington, DC

The Trading Mesh (2011a) High frequency trading in India: Citihub conversations, Part 2. London, UK, June 13

The Trading Mesh (2011b) SGX Singapore launches co-location. London, UK, April 19

Tufano P (1989) Financial innovation and first-mover advantages. Journal of Financial Economics 25(2):213-240

Umeno J, Matsubara H (2014) Changing tick sizes in Japan. Global Trading, Hong Kong, China, September 22

United States Commodity and Futures Trading Commission (2012) Technology Advisory Committee Subcommittee on Automated and High Frequency Trading, Working Group 1, Washington, DC, October 30

United States Senate (2009) Hearings: dark pools, flash orders, high frequency trading, and other market structure issues. Committee on Banking, Housing and Urban Affairs, Washington, DC, October 28

Valentine B, Misra N (2012) Algorithms in emerging ASEAN markets. The Trade, London, UK

Valentino S (2014) The dark side. Philstar Business, Manila, Philippines, April 14

Wang F (2010) TSE's arrowhead system lowers trading costs. Securities Industry News, Trombly International, Hong Kong, China, March 11

Weston JP (2002) Electronic communication networks and liquidity on the NASDAQ. Journal of Financial Services Research 22(1-2):125-139

World Federation of Exchanges (2013) Understanding high-frequency trading (HFT). London, UK, May 29

Wriston WB (1988) Technology and sovereignty. Foreign Affairs 67(2):63-75

Wriston WB (2007) Bits, bytes and balance sheets: the new economic rules of engagement in a wireless world. Publication 557, Hoover Institution, Washington, DC

Yoon H (2010) Changes to the Japanese equity market as visualised by NEEDS-TickVision: a look at how the launch of TSE Arrowhead has changed equity trading in Tokyo. NEEDS report, Nikkei / CMD Laboratories Inc, Tokyo, Japan

Zhang F (2010) High-frequency trading, stock volatility, and price discovery. Working paper, School of Management, Yale University, New Haven, CT

\section{Submit your manuscript to a SpringerOpen ${ }^{\circ}$ journal and benefit from:}

- Convenient online submission

- Rigorous peer review

- Immediate publication on acceptance

Open access: articles freely available online

- High visibility within the field

- Retaining the copyright to your article 